ISSN 0258-7122 (Print), 2408-8293 (Online)

Bangladesh J. Agril. Res. 43(1): 39-51, March 2018

\title{
HEAVY METAL ACCUMULATION IN LEAFY VEGETABLES GROWN IN INDUSTRIAL AREAS UNDER VARYING LEVELS OF POLLUTION
}

\author{
H. M. NASER ${ }^{1}$, M. Z. RAHMAN ${ }^{2}$, S. SULTANA ${ }^{3}$ \\ M. A. QUDDUS ${ }^{4}$ AND M. A. HOSSAIN ${ }^{5}$
}

\begin{abstract}
The concentration of lead $(\mathrm{Pb})$, cadmium $(\mathrm{Cd})$, nickel $(\mathrm{Ni})$, cobalt $(\mathrm{Co})$ and chromium $(\mathrm{Cr})$ in three popular leafy vegetables such as spinach (Spinacia oleracea), red amaranth (Amaranthus tricolor) and amaranth (Amaranthus oleraseus) and that in the respective soils were assessed. These crops and soils were collected from two industrial areas (Kalakoir and Zorun, Konabari, Gazipur), and one non-industrial area (Bangladesh Agricultural Research Institute-BARI) under Gazipur district. The concentration of heavy metal in different parts of plant followed the roots $>$ leaves $>$ stem and in soils the order was Kalakoir (pollution)> Zorun (medium pollution) > BARI (low/nonpollution). In all three leafy vegetables similar trend of metal contents was observed i.e. $\mathrm{Ni}>\mathrm{Cr}>\mathrm{Pb}>\mathrm{Co}>\mathrm{Cd}$. In the highly pollution area (Kalakoir) the $\mathrm{Pb}$ and $\mathrm{Ni}$ concentration was found in the order of amaranth $>$ spinach $>$ red amaranth. The $\mathrm{Cd}$ concentration was in the order of spinach>amaranth>red amaranth whereas for $\mathrm{Cd}$ it was amaranth>red amaranth>spinach and for $\mathrm{Cr}$ it was red amaranth>amaranth>spinach. The $\mathrm{Pb}, \mathrm{Cd}, \mathrm{Ni}, \mathrm{Co}$ and $\mathrm{Cr}$ concentrations in the studied vegetables grown in the low polluted area were below the maximum acceptable levels proposed by the Joint FAO/WHO Expert Committee on Food Additives, except, $\mathrm{Cd}$ in spinach and amaranth. However, the higher concentrations of $\mathrm{Pb}, \mathrm{Cd}, \mathrm{Ni}, \mathrm{Co}$ and $\mathrm{Cr}$ in vegetables grown in the industrial areas indicates that industrial discharge causes heavy metals contamination of soil and eventually their accumulation in plants.
\end{abstract}

Keywords: Leafy vegetables, heavy metal, industrial areas.

\section{Introduction}

Anthropogenic activities have altered the environment significantly throughout the world including mining, industry and agriculture as well as increase of the urbanization level (Wang et al., 2008). Disposal of sewage water and industrial wastes is a great problem. Often it is drained to the agricultural lands where it is used for growing crops including vegetables. These sewage effluents are considered not only a rich source of organic matter and some nutrients, but these also elevate the level of heavy metals like iron $(\mathrm{Fe})$, manganese $(\mathrm{Mn})$, copper

${ }^{1}$ Principal Scientific Officer, Soil Science Division, Bangladesh Agricultural Research Institute (BARI), Joydebpur, Gazipur-1701, ${ }^{2}$ Assistant Professor, School of Business Studies, North South University (NSU), Dhaka, ${ }^{3}$ Scientific Officer, Soil Science Division BARI, Joydebpur, Gazipur-1701, ${ }^{4}$ Senior Scientific Officer, HRC, BARI, Gazipur-1701, ${ }^{5}$ Chief Scientific Officer, Soil Science Division, BARI, Joydebpur, Gazipur-1701, Bangladesh. 
$(\mathrm{Cu})$, zinc $(\mathrm{Zn})$, lead $(\mathrm{Pb})$, chromium $(\mathrm{Cr})$, nickel $(\mathrm{Ni})$, cadmium $(\mathrm{Cd})$, and cobalt (Co) in soils (Singh et al., 2004).

In the low concentrations, many metals are essential to life (Kashif et al., 2009). Trace quantities of certain heavy elements such as $\mathrm{Co}, \mathrm{Cu}, \mathrm{Mn}$ and $\mathrm{Zn}$ are essential micronutrients for higher animals and for plants (Somers, 1974). However, excessive accumulation of trace elements in agricultural soils through wastewater irrigation may not only result in soil contamination, but it also affects food quality and safety (Muchuweti et al., 2006; Sharma et al., 2007). Some trace elements are essential in plant nutrition, but plants growing in the nearby zone of industrial areas accumulate increased concentration of heavy metals, serving in many cases as bio monitors of pollution loads (Mingorance et al., 2007).

Vegetables are an important part of human's diet. It is potential source of nutrients which have marked health effects (Arai, 2002). Vegetables are plants that are eaten raw or cooked. It is described as shrubs or herbaceous annual or perennial plants that are eaten by man (Longman, 2005). There are different kinds of vegetables ranging from edible roots, stems, leaves, fruits or seeds. Each group contributes to diet in its own way (Hanif et al., 2006). Vegetables cultivated in soils polluted with toxic metals due to industrial activities take up heavy metals and accumulate them in their edible and non-edible parts in quantities high enough to cause clinical problems both to animals and human beings consuming these metal-rich plants because there is no good mechanism for their elimination from the human body (Alam et al., 2003; Arora et al., 2008). Trace elements are harmful because of their nonbiodegradable nature, long biological half-lives, and their potential to accumulate in different body parts.

Vegetables, especially those of leafy vegetables grown in heavy metals contaminated soils, accumulate higher amounts of metals than those grown in uncontaminated soils (Al Jassir et al., 2005). Previous study revealed that the concentrations of metal in vegetables varied with the locations, showing the trend: high-level of pollution> medium-level of pollution> low-level of pollution (Naser et al., 2009). The present study was carried out in industrial areas of Turag River vicinity, Gazipur, Bangladesh, where irrigation of vegetable crops with polluted river water is a common practice. Knowledge about contamination of vegetables with heavy metals from industrial areas of Turag River vicinity is yet to be obtained. In this context, the present study was undertaken to investigate the concentration of heavy metals $(\mathrm{Pb}, \mathrm{Cd}, \mathrm{Ni}, \mathrm{Co}$ and $\mathrm{Cr}$ ) in commonly grown leafy vegetables and their level in respective crop-soils.

\section{Materials and Methods}

\section{Soil and plant sampling}

Soil and leafy vegetables samples were taken from three cropping areas exposed to different degrees of pollution. Area 1- high-level of pollution: Pollution by 
irrigation water (Kalakoir, Konabari, Gazipur- 2359'32.65"N, 90 ${ }^{\circ} 19^{\prime} 43.43^{\prime \prime} \mathrm{E}$ ), the vegetable samples in this area were taken from the site irrigated with the Turag river water. The river Turag is highly polluted by industrial effluents, sewage sludge, municipal waste water and urban pollution (Islam et al., 2012b). Area 2- medium-level of pollution: Pollution by pond and kennel's water (Zorun, Konabari, Gazipur- $\left.23^{\circ} 59^{\prime} 53.38^{\prime \prime} \mathrm{N}, 90^{\circ} 19^{\prime} 21.77^{\prime \prime} \mathrm{E}\right)$, which is polluted by industrial effluents, sewage sludge, municipal waste water and urban pollution. During rainy season pond and canals are over flown by rain water and submerse the adjacent cultivable land where the farmers grow their vegetables in winter. Area 3- low-level of pollution: The same vegetables samples and soils were collected from BARI (Bangladesh Agricultural Research Institute$23^{\circ} 59^{\prime} 31.15^{\prime \prime} \mathrm{N}, 90^{\circ} 24^{\prime} 50.95^{\prime \prime} \mathrm{E}$ ), experimental field, regarded as low-level pollution area. The collected plant samples included spinach (Spinacia oleracea), red amaranth (Amaranthus tricolor) and amaranth (Amaranthus oleraseus). Plant samples were collected from 6 week olds plants. Soil and vegetable samples were collected from different sites of each location. The plant samples represented different parts of plant roots, stem and leaves. Soil samples of $0-15 \mathrm{~cm}$ depth were collected by a stainless steel auger at the same time when vegetable samples were collected, and samples were taken to the laboratory.

\section{Preparation and preservation}

In the laboratory, all vegetables were washed with fresh running water to remove dust, dirty materials, possible parasites or their eggs and then were again washed with deionized water. The clean vegetable samples were air-dried and placed in an electric oven at $65{ }^{\circ} \mathrm{C}$ for $72-96 \mathrm{~h}$ depending on the sample size. The samples were homogenized by grinding using a ceramic coated grinder. All soil samples were spread on plastic trays and allowed to dry at ambient temperature for one week. Soil $\mathrm{pH}$ was determined by glass electrode $\mathrm{pH}$ meter and electricity conductivity (EC) was measured by conductivity meter in 1:5 ratio of soilwater suspension (Yong et al., 2011). The dry samples of soils were ground with a ceramic coated grinder and sieved through a nylon sieve. The final samples were kept in labeled polypropylene containers at ambient temperature before analysis.

\section{Digestion and determination}

The samples were digested with $\mathrm{HNO}_{3}$ and $\mathrm{HClO}_{4}$ (5:1 volume) for total metal estimation, as described by Misra and Chaturvedi (2007). One gram of each sample was weighed into 50-ml beaker, followed by the addition of $10 \mathrm{ml}$ mixture of analytical grade acids $\mathrm{HNO}_{3}: \mathrm{HCIO}_{4}$ in the ratio 5:1, and left overnight for complete contact of material. Next day, the digestion was performed at a temperature of about $190{ }^{\circ} \mathrm{C}$ for $1.5 \mathrm{~h}$. After cooling, the samples were transferred into $50 \mathrm{ml}$ volumetric flask and solution was made up to a final volume raised up to the mark with distilled water. The metal concentrations were determined by atomic absorption spectrometry using a VARIAN model AA2407 
Atomic Absorption Spectrophotometer (AAS). Analysis of each sample was carried out three times to obtain representative results and the data reported in $\mu \mathrm{g}$ $\mathrm{g}^{-1}$ (on a dry matter basis). Statistical differences were judged by Tukey's multiple comparisons test by using Excel Statistics version 4.0 (Esumi Co. Ltd., Tokyo, Japan).

\section{Results and Discussion}

\section{Chemical properties of soils}

The $\mathrm{pH}$ of soil samples from high-level and medium-level pollution area was 6.58 and 6.60 , respectively, which indicates that the soils were slightly acidic to neutral. On the other hand $\mathrm{pH}$ from low-level pollution area was slightly alkaline in reaction $\mathrm{pH}$ (7.43). These $\mathrm{pH}$ values from polluted area (either high-level or medium-level) were within the range of the $\mathrm{pH}$ of the surface soils (ranged from 6.10 to 6.98 ) from the solid waste dumping site near to the present study area (Islam et al., 2012a). The study revealed that the EC of the high-level polluted soils receiving irrigation with industrial effluents was higher (3.26 deciSiemens per meter $\left.-\mathrm{dS} \mathrm{m}^{-1}\right)$ than the soils of medium-level polluted $\left(1.15 \mathrm{dS} \mathrm{m}^{-1}\right)$, and the value of EC was lowest in low-level polluted area $\left(0.61 \mathrm{dS} \mathrm{m}^{-1}\right)$. The presence of large amount of ionic substance and soluble salts have resulted in increased value of EC in the industrial effluents contaminated irrigated soil samples in comparison to the others (Islam et al., 2012a).

\section{Heavy metal contents in plant parts}

The mean concentrations of $\mathrm{Pb}, \mathrm{Cd}, \mathrm{Ni}, \mathrm{Co}$, and $\mathrm{Cr}$ in different parts (roots, stem, and leaves) of vegetables studied were given in Tables $1-3$. The concentrations of heavy metals in these samples were quite variable such as $0.64-5.97 \mu \mathrm{g} \mathrm{g}^{-1}$ for $\mathrm{Pb}, 0.22-1.28 \mu \mathrm{g} \mathrm{g}^{-1}$ for $\mathrm{Cd}, 4.02-46.5 \mu \mathrm{g} \mathrm{g}^{-1}$ for $\mathrm{Ni}, 0.39-2.62 \mu \mathrm{g} \mathrm{g}^{-1}$ for $\mathrm{Co}$, and 1.71-6.99 $\mu \mathrm{g} \mathrm{g}^{-1}$ for $\mathrm{Cr}$. It was observed that high contents of $\mathrm{Cd}, \mathrm{Ni}$ and $\mathrm{Cr}$ were accumulated in roots of spinach $\left(1.28,46.5\right.$ and $2.62 \mu \mathrm{g} \mathrm{g}^{-1}$, respectively) grown on high-level polluted area. The spinach exhibited higher levels of $\mathrm{Pb}(5.97 \mu \mathrm{g} \mathrm{g}$ $\left.{ }^{1}\right)$ in leaves followed by red amaranth, while stem of red amaranth in low-level polluted area showed low concentration of $\mathrm{Pb}\left(0.64 \mu \mathrm{g} \mathrm{g}^{-1}\right)$. The lowest concentration of Co $\left(0.39 \mu \mathrm{g} \mathrm{g}^{-1}\right)$ was observed in spinach stem. On the other hand, amaranth roots showed the highest concentration of Co $\left(2.62 \mu \mathrm{g} \mathrm{g}^{-1}\right)$. Present study revealed that all the heavy metal content was found greater in spinach grown in polluted areas (either high-level or medium-level), only Co was found greater in roots of amaranth in the same location. With few exceptions, the magnitude of heavy metals detected in various plant components particularly in roots, stems and leaves was found as roots>leaves>stem. Content of heavy metal in different parts of vegetables followed the trend as high-level of pollution> medium-level of pollution> low-level of pollution. 
The mean concentrations of $\mathrm{Pb}, \mathrm{Cd}, \mathrm{Ni}, \mathrm{Co}$ and $\mathrm{Cr}$ in whole plant (roots, stem and leaves) of three leafy vegetables were shown in Table 4 . The concentrations of heavy metals ( $\mu \mathrm{g} \mathrm{g}^{-1}$ of dry wt.) in those vegetables quite varied, such as $\mathrm{Pb}$ ( 0.76 to $\left.5.73 \mu \mathrm{g} \mathrm{g}^{-1}\right), \mathrm{Cd}\left(0.29\right.$ to $\left.1.14 \mu \mathrm{g} \mathrm{g}^{-1}\right)$, Ni (4.94 to $\left.33.8 \mu \mathrm{g} \mathrm{g}^{-1}\right)$, Co (0.49 to $\left.2.38 \mu \mathrm{g} \mathrm{g}^{-1}\right)$ and $\mathrm{Cr}\left(2.23\right.$ to $\left.6.67 \mu \mathrm{g} \mathrm{g}^{-1}\right)$. The levels of heavy metal in all the three vegetable samples from the polluted area (either high-level or mediumlevel) were higher than those from the low-level polluted (BARI) area. Several studies have indicated that vegetables grown in heavy metals contaminated soils have higher concentrations of heavy metals than those grown in uncontaminated soils (Al Jassir et al., 2005; Farooqet et al., 2008).

Statistically significant difference $(P<0.01)$ in heavy metal $(\mathrm{Pb}, \mathrm{Cd}, \mathrm{Ni}, \mathrm{Co}$, and $\mathrm{Cr}$ ) contents was found between polluted (either high-level or medium-level) and non-polluted areas in both vegetables and soils. For all the three vegetables and for all locations a similar trend in metal contents was observed i.e. $\mathrm{Ni}>\mathrm{Cr}>\mathrm{Pb}>\mathrm{Co}>\mathrm{Cd}$ and the magnitude of heavy metal contamination was highlevel of pollution> medium-level of pollution> non-pollution. However, their values in all vegetables were different. In high-level polluted area the extent of heavy metal content in vegetables can be regarded in the order of amaranth $>$ spinach $>$ red amaranth for $\mathrm{Pb}$, spinach $>$ amaranth $>$ red amaranth for $\mathrm{Cd}$, amaranth $>$ spinach $>$ red amaranth for $\mathrm{Ni}$, amaranth $>$ red amaranth $>$ spinach for $\mathrm{Co}$ and red amaranth>amaranth $>$ spinach for $\mathrm{Cr}$.

Proportion of heavy metal contents increased (\%) in spinach, red amaranth and amaranth in high-level polluted and medium-level polluted areas in comparison to non-polluted area showing a range from 253 to $451 \%, 489$ to $507 \%$ and 394 to $429 \%$ for $\mathrm{Pb} ; 27$ to $139 \%, 176$ to $197 \%$ and 61 to $128 \%$ for $\mathrm{Cd} ; 461$ to $553 \%$, 466 to $528 \%$ and 349 to $567 \%$ for Ni, it was 188 to $227 \%, 134$ to $177 \%$ and 65 to $95 \%$ for Co; and was 115 to $142 \%, 165$ to $174 \%$ and 185 to $198 \%$ for $\mathrm{Cr}$, respectively.

In our previous study (Naser et al., 2009), we determined the levels of $\mathrm{Pb}, \mathrm{Cd}$ and $\mathrm{Ni}$ in samples of spinach, tomato and cauliflower $0.767-1.440 \mu \mathrm{g} \mathrm{g}^{-1}, 1.027$ $1.968 \mu \mathrm{g} \mathrm{g}^{-1}, 0.486-1.119 \mu \mathrm{g} \mathrm{g}^{-1}$, respectively for $\mathrm{Pb}$; 0.559-1.40 $\mu \mathrm{g} \mathrm{g}^{-1}, 0.630$ $1.303 \mu \mathrm{g} \mathrm{g}^{-1}, 0.506-0.782 \mu \mathrm{g} \mathrm{g}^{-1}$, respectively for $\mathrm{Cd}$ and $1.265-5.369 \mu \mathrm{g} \mathrm{g}^{-1}$, 2.031-4.957 $\mu \mathrm{g} \mathrm{g}^{-1}, 1.698-4.447 \mu \mathrm{g} \mathrm{g}^{-1}$, respectively for $\mathrm{Ni}$, grown in industrially (Konabari, Gazipur; Keranigonj, Dhaka), and non-industrial (Bangladesh Agricultural Research Institute-BARI, Gazipur) areas. The reported $\mathrm{Cd}$ concentrations were found similar to the current levels but the $\mathrm{Pb}$ and $\mathrm{Ni}$ concentrations were higher than the reported values. The higher concentrations of $\mathrm{Pb}$ and $\mathrm{Ni}$ might be due to the differences in location. On the other hand, concentrations of $\mathrm{Pb}$ and $\mathrm{Ni}$ in spinach from BARI were higher than those from previous study (Naser et al., 2009). It might be due to the experimental field, which was top-dressed by foreign soil near about couple of years before. So, it is not representing the previous tested soils. 
The $\mathrm{Pb}$ levels in vegetables in this study were higher than the reported values (Alegria et al., 1991; Jamali et al., 2007). For example, the levels of $\mathrm{Pb}$ in spinach grown in the waste water irrigation area (TVS) was $0.12 \mu \mathrm{g} \mathrm{g}^{-1}$ dry wt., while the cannel water irrigation area (CVS) showed $0.330 .12 \mu \mathrm{g} \mathrm{g}^{-1}$ dry wt. (Jamali et al., 2007). The Pb concentration in all the vegetables from polluted areas (either high-level or medium-level) was above the permissible levels (Table 4) of India (Awashthi, 2000) and was lower or similar with the maximum level as per FAO/WHO standard (FAO/WHO - Codex Alimentarious Commission, 1984), except, $\mathrm{Pb}$ content in amaranth from polluted area. On the other hand, the $\mathrm{Pb}$ levels in this study were lower than the concentrations of $\mathrm{Pb}(17.5-25.0 \mu \mathrm{g} \mathrm{g}$ ${ }^{1}$ ) in vegetables grown in wastewater treated areas of Varanasi, India (Sharma et al., 2006) and the levels of $\mathrm{Pb}\left(6.77 \mu \mathrm{g} \mathrm{g}^{-1}\right)$ in vegetables irrigated with mixtures of wastewater and sewage from Zimbabwe (Muchuweti et al., 2006).

Table1. Concentration ( \pm , standard deviation) of $\mathrm{Pb}, \mathrm{Cd}, \mathrm{Ni}, \mathrm{Co}$ and $\mathrm{Cr}$ in the roots of three leafy vegetables grown in areas with different levels of pollution by heavy metals

\begin{tabular}{c|c|c|c|c|c|c}
\hline \multirow{2}{*}{ Vegetable } & $\begin{array}{c}\text { Level of } \\
\text { pollution in } \\
\text { the growing } \\
\text { area }\end{array}$ & \multicolumn{5}{|c}{ Concentration $\left(\mu \mathrm{g} \mathrm{g}^{-1}\right.$ of dry wt. $)$} \\
\cline { 3 - 7 } & $\mathrm{Pb}$ & $\mathrm{Cd}$ & $\mathrm{Ni}$ & $\mathrm{Co}$ & $\mathrm{Cr}$ \\
\hline \multirow{5}{*}{ Spinach } & High & $4.87 \pm 0.35$ & $1.28 \pm 0.54$ & $46.5 \pm 2.63$ & $1.78 \pm 0.25$ & $6.99 \pm 0.78$ \\
& Medium & $3.08 \pm 0.35$ & $0.66 \pm 0.06$ & $40.8 \pm 3.11$ & $1.54 \pm 0.19$ & $5.64 \pm 0.16$ \\
& Low & $0.90 \pm 0.11$ & $0.51 \pm 0.09$ & $5.23 \pm 0.88$ & $0.61 \pm 0.08$ & $2.73 \pm 0.34$ \\
\hline \multirow{2}{*}{ Red } & High & $3.71 \pm 0.53$ & $1.02 \pm 0.18$ & $46.3 \pm 2.38$ & $2.37 \pm 0.23$ & $6.90 \pm 0.64$ \\
Amaranthyyyyyyy & Medium & $3.67 \pm 0.75$ & $0.86 \pm 0.21$ & $40.0 \pm 2.87$ & $2.10 \pm 0.22$ & $6.58 \pm 0.58$ \\
& Low & $0.79 \pm 0.19$ & $0.40 \pm 0.03$ & $5.75 \pm 0.90$ & $1.01 \pm 0.13$ & $3.02 \pm 0.39$ \\
\hline \multirow{5}{*}{ Amaranth } & High & $5.94 \pm 0.45$ & $1.20 \pm 0.47$ & $37.8 \pm 2.20$ & $2.62 \pm 0.27$ & $6.55 \pm 0.46$ \\
& Ledium & $6.08 \pm 1.06$ & $0.80 \pm 0.13$ & $24.9 \pm 1.89$ & $2.02 \pm 0.09$ & $6.45 \pm 0.29$ \\
\hline
\end{tabular}

Vegetables from the polluted (either high-level or medium-level) area showed higher levels of $\mathrm{Cd}$ than those from the low-level polluted area (Table 1-3). In fact, significant differences $(P<0.01)$ were found in the level of $\mathrm{Cd}$ in all tested vegetables between polluted (either high-level or medium-level) and low-level polluted areas. The above results obtained are in line with Lone et al., (2003), who studied the effect of sewage and tubewell water on heavy metal content of spinach in Pakistan, they found considerably higher concentration of $\mathrm{Cd}$ than those soils irrigated with tubewell water. Our study also showed that the average $\mathrm{Cd}$ levels measured in vegetables were higher than that in leafy and non-leafy vegetables in India (Tripathi et al., 1997). Similar to $\mathrm{Pb}$ as reported by the group 
of researchers (Jamali et al., 2007), the concentration of $\mathrm{Cd}$ in vegetables sampled from TVS was high $0.14 \mu \mathrm{g} \mathrm{g}^{-1}$ (spinach) on a dry wt. basis, whereas in CVS showed $0.01 \mu \mathrm{g} \mathrm{g}^{-1}$. The $\mathrm{Cd}$ concentration was below the Indian standard (Awashthi, 2000) but above the safe levels of FAO/WHO and China (SEPA, 2005). The Ni concentrations in vegetables in this study were higher compared to the $\mathrm{Pb}$ and $\mathrm{Cd}$ concentrations, and the heavy metal concentration from industrial area was higher than that from non-industrial area (Yusuf et al., 2003). The $\mathrm{Ni}$ concentration was below the safe level as demonstrated by FAO/WHO and it was above the safe levels of Indian standard (Awashthi, 2000) and China (SEPA, 2005). The maximum Co concentration $\left(2.38 \mu \mathrm{g} \mathrm{g}^{-1}\right.$ dry wt.) was found in amaranth whereas the mean value was 2.27 and $1.60 \mu \mathrm{g} \mathrm{g}^{-1}$ dry wt. for red amaranth and spinach, respectively, which was lower than the mean value 9.2 to $11.3 \mu \mathrm{g} \mathrm{g}^{-1}$ dry wt., for garden spinach in India (Farooq et al., 1999). Cobalt concentration was below the safe levels of FAO/WHO. The mean levels of $\mathrm{Cr}$ in vegetables in the present study were significantly lower than the concentrations of other reported studies (Gupta et al., 2008; Sharma et al., 2007) in India. However, it was close to the result obtained from past study in Bangladesh (Ahmad and Goni, 2009) and in China (Liu et al., 2006). Chromium concentration in all the vegetables from polluted areas (either high-level or medium-level) examined in the present study was above the permissible levels recommended by FAO/WHO and China (SEPA, 2005) but below the maximum limit for India (Awashthi, 2000).

Table 2. Concentration ( \pm , standard deviation) of $\mathrm{Pb}, \mathrm{Cd}, \mathrm{Ni}, \mathrm{Co}$ and $\mathrm{Cr}$ in the stem of three leafy vegetables grown in areas with different levels of pollution by heavy metals

\begin{tabular}{c|c|c|c|c|c|c}
\hline \multirow{2}{*}{ Vegetable } & $\begin{array}{c}\text { Level of } \\
\text { pollution in } \\
\text { the growing } \\
\text { area }\end{array}$ & \multicolumn{5}{|c}{ Concentration $\left(\mu \mathrm{g} \mathrm{g}^{-1}\right.$ of dry wt. $)$} \\
\cline { 3 - 7 } & $\mathrm{Pb}$ & $\mathrm{Cd}$ & $\mathrm{Ni}$ & $\mathrm{Co}$ & $\mathrm{Cr}$ \\
\hline \multirow{5}{*}{ Spinach } & High & $4.37 \pm 0.49$ & $1.11 \pm 0.16$ & $21.3 \pm 2.25$ & $1.40 \pm 0.27$ & $5.57 \pm 0.57$ \\
& Medium & $3.06 \pm 0.22$ & $0.64 \pm 0.09$ & $20.0 \pm 2.76$ & $1.28 \pm 0.12$ & $5.02 \pm 0.92$ \\
& Low & $0.70 \pm 0.12$ & $0.49 \pm 0.16$ & $4.55 \pm 0.70$ & $0.39 \pm 0.06$ & $2.15 \pm 0.53$ \\
\hline \multirow{2}{*}{ Red } & High & $4.53 \pm 0.47$ & $0.74 \pm 0.15$ & $24.1 \pm 3.33$ & $2.14 \pm 0.20$ & $6.34 \pm 0.77$ \\
Amaranthyyyyyyy & Medium & $4.39 \pm 0.43$ & $0.80 \pm 0.18$ & $21.9 \pm 1.64$ & $1.63 \pm 0.29$ & $6.92 \pm 0.15$ \\
& Low & $0.64 \pm 0.12$ & $0.22 \pm 0.06$ & $4.02 \pm 0.58$ & $0.64 \pm 0.09$ & $2.50 \pm 0.30$ \\
\hline \multirow{5}{*}{ Amaranth } & High & $5.50 \pm 0.42$ & $1.02 \pm 0.33$ & $34.3 \pm 2.26$ & $2.23 \pm 0.16$ & $6.45 \pm 0.29$ \\
& Ledium & $4.26 \pm 0.27$ & $0.67 \pm 0.18$ & $22.2 \pm 3.58$ & $1.98 \pm 0.16$ & $6.07 \pm 0.81$ \\
\hline
\end{tabular}


Table 3. Concentration ( \pm , standard deviation) of $\mathrm{Pb}, \mathrm{Cd}, \mathrm{Ni}, \mathrm{Co}$ and $\mathrm{Cr}$ in the leaves of three leafy vegetables grown in areas with different levels of pollution by heavy metals

\begin{tabular}{|c|c|c|c|c|c|c|}
\hline \multirow{2}{*}{ Vegetable } & \multirow{2}{*}{$\begin{array}{l}\text { Level of } \\
\text { pollution in } \\
\text { the growing } \\
\text { area }\end{array}$} & \multicolumn{5}{|c|}{ Concentration ( $\mu \mathrm{g} \mathrm{g}^{-1}$ of dry wt.) } \\
\hline & & $\mathrm{Pb}$ & $\mathrm{Cd}$ & $\mathrm{Ni}$ & Co & $\mathrm{Cr}$ \\
\hline \multirow{3}{*}{ Spinach } & High & $5.97 \pm 0.30$ & $1.02 \pm 0.15$ & $31.9 \pm 3.38$ & $1.63 \pm 0.24$ & $5.70 \pm 0.36$ \\
\hline & Medium & $3.61 \pm 0.18$ & $0.52 \pm 0.03$ & $24.6 \pm 2.23$ & $1.41 \pm 0.17$ & $5.62 \pm 0.23$ \\
\hline & Low & $1.16 \pm 0.16$ & $0.43 \pm 0.07$ & $5.48 \pm 0.47$ & $0.47 \pm 0.09$ & $2.69 \pm 0.24$ \\
\hline \multirow{3}{*}{$\begin{array}{c}\text { Red } \\
\text { Amaranth }\end{array}$} & High & $5.51 \pm 0.35$ & $0.85 \pm 0.14$ & $22.5 \pm 3.68$ & $2.31 \pm 0.15$ & $6.76 \pm 0.12$ \\
\hline & Medium & $5.29 \pm 0.65$ & $0.77 \pm 0.12$ & $22.1 \pm 1.79$ & $2.02 \pm 0.30$ & $5.82 \pm 0.51$ \\
\hline & Low & $0.85 \pm 0.15$ & $0.23 \pm 0.02$ & $5.04 \pm 0.62$ & $0.80 \pm 0.07$ & $1.77 \pm 0.22$ \\
\hline \multirow{3}{*}{ Amaranth } & High & $5.75 \pm 0.38$ & $0.78 \pm 0.22$ & $29.3 \pm 2.48$ & $2.30 \pm 0.15$ & $6.93 \pm 0.40$ \\
\hline & Medium & $5.70 \pm 1.07$ & $0.68 \pm 0.15$ & $21.1 \pm 3.54$ & $2.02 \pm 0.03$ & $6.52 \pm 0.43$ \\
\hline & Low & $0.89 \pm 0.03$ & $0.30 \pm 0.08$ & $4.99 \pm 0.61$ & $1.27 \pm 0.16$ & $1.71 \pm 0.33$ \\
\hline
\end{tabular}

Table 4. Concentration ( \pm , standard deviation) of $\mathrm{Pb}, \mathrm{Cd}, \mathrm{Ni}, \mathrm{Co}$ and $\mathrm{Cr}$ in whole plant (roots, stem and leaves) of three leafy vegetables grown in areas with different levels of pollution by heavy metals

\begin{tabular}{c|c|c|c|c|c|c}
\hline \multirow{2}{*}{ Vegetable } & $\begin{array}{c}\text { Level of } \\
\text { pollution i } \\
\text { the growing } \\
\text { area }\end{array}$ & \multicolumn{5}{|c}{ Concentration $\left(\mu \mathrm{g} \mathrm{g}^{-1}\right.$ of dry wt. } \\
\cline { 3 - 8 } & High & $5.07 \pm 0.79 \mathrm{c}$ & $1.14 \pm 0.31 \mathrm{c}$ & $33.2 \pm 11.2 \mathrm{~b}$ & $1.60 \pm 0.27 \mathrm{~b}$ & $6.09 \pm 0.85 \mathrm{~b}$ \\
\hline \multirow{2}{*}{ Spinach } & Medium & $3.25 \pm 0.35 \mathrm{~b}$ & $0.61 \pm 0.09 \mathrm{~b}$ & $28.5 \pm 9.74 \mathrm{~b}$ & $1.41 \pm 0.18 \mathrm{~b}$ & $5.43 \pm 0.57 \mathrm{~b}$ \\
& Low & $0.92 \pm 0.23 \mathrm{a}$ & $0.48 \pm 0.10 \mathrm{a}$ & $5.09 \pm 0.74 \mathrm{a}$ & $0.49 \pm 0.12 \mathrm{a}$ & $2.52 \pm 0.44 \mathrm{a}$ \\
\hline \multirow{2}{*}{ Red } & High & $4.59 \pm 0.87 \mathrm{~b}$ & $0.87 \pm 0.18 \mathrm{~b}$ & $31.0 \pm 11.8 \mathrm{~b}$ & $2.27 \pm 0.20 \mathrm{~b}$ & $6.67 \pm 0.56 \mathrm{~b}$ \\
Amaranth & Medium & $4.45 \pm 0.89 \mathrm{~b}$ & $0.81 \pm 0.16 \mathrm{~b}$ & $28.0 \pm 9.21 \mathrm{~b}$ & $1.92 \pm 0.32 \mathrm{~b}$ & $6.44 \pm 0.63 \mathrm{~b}$ \\
& Low & $0.76 \pm 0.16 \mathrm{a}$ & $0.29 \pm 0.09 \mathrm{a}$ & $4.94 \pm 0.97 \mathrm{a}$ & $0.82 \pm 0.18 \mathrm{a}$ & $2.43 \pm 0.61 \mathrm{a}$ \\
\hline \multirow{2}{*}{ Amaranth } & Migh & $5.73 \pm 0.41 \mathrm{c}$ & $1.00 \pm 0.35 \mathrm{c}$ & $33.8 \pm 4.20 \mathrm{c}$ & $2.38 \pm 0.25 \mathrm{~b}$ & $6.64 \pm 0.40 \mathrm{~b}$ \\
& Medium & $5.35 \pm 1.13 \mathrm{~b}$ & $0.71 \pm 0.15 \mathrm{~b}$ & $22.7 \pm 3.19 \mathrm{~b}$ & $2.01 \pm 0.10 \mathrm{~b}$ & $6.35 \pm 0.52 \mathrm{~b}$ \\
\hline \multirow{2}{*}{ Safe Limit $\left(\mu \mathrm{gg}{ }^{-1}\right)^{\mathrm{a}}$} & $1.08 \pm 0.45 \mathrm{a}$ & $0.44 \pm 0.15 \mathrm{a}$ & $5.06 \pm 0.49 \mathrm{a}$ & $1.22 \pm 0.35 \mathrm{a}$ & $2.23 \pm 0.47 \mathrm{a}$ \\
\hline
\end{tabular}

Mean values in the same column followed by the same letters are not significantly different $(P<0.01)$.

${ }^{a}$ FAO/WHO-Codex Alimentarious Commission (1984).

\section{Heavy metal contents in soils}

Lead, Cd, Ni, Co and $\mathrm{Cr}$ concentrations in soil samples (Table 5) followed a trend similar to vegetables heavy metals concentrations of vegetables. Thus, the 
increase of metal contents $\left(\mu \mathrm{g} \mathrm{g}^{-1}\right)$ in soils of medium-level and high-level polluted areas were 109 to $274 \%, 104$ to $173 \%$ and 112 to $269 \%$ for $\mathrm{Pb} ; 126$ to $187 \%, 162$ to $164 \%$ and 119 to $157 \%$ for Cd; 132 to $185 \%, 169$ to $189 \%$ and 102 to $171 \%$ for $\mathrm{Ni}$; it was 151 to $212 \%, 171$ to $250 \%$ and 269 to $286 \%$ for $\mathrm{Co}$; and was 142 to $174 \%, 151$ to $178 \%$ and 154 to $159 \%$ for $\mathrm{Cr}$, respectively. Comparing the metal concentration in soil with guidelines for soils showed that all metal concentration was below the safe limits for soils (Table 5).

Table 5. Concentration ( \pm , standard deviation) of $\mathrm{Pb}, \mathrm{Cd}, \mathrm{Ni}, \mathrm{Co}$ and $\mathrm{Cr}$ in soils of three leafy vegetables from areas with different levels of pollution by heavy metals

\begin{tabular}{c|l|c|c|c|c|c}
\hline \multirow{2}{*}{ Vegetable } & $\begin{array}{c}\text { Level of } \\
\text { pollution in } \\
\text { the growing } \\
\text { area }\end{array}$ & $\mathrm{Pb}$ & $\mathrm{Cd}$ & $\mathrm{Ni}$ & $\mathrm{Co}$ & $\mathrm{Cr}$ \\
\cline { 3 - 7 } & & & & & & \\
\hline \multirow{3}{*}{ Spinach } & High & $17.5 \pm 0.55 \mathrm{c}$ & $2.03 \pm 0.08 \mathrm{c}$ & $39.9 \pm 1.10 \mathrm{c}$ & $14.3 \pm 1.28 \mathrm{~b}$ & $32.3 \pm 1.40 \mathrm{~b}$ \\
& Medium & $9.75 \pm 1.23 \mathrm{~b}$ & $1.60 \pm 0.16 \mathrm{~b}$ & $32.5 \pm 1.60 \mathrm{~b}$ & $11.5 \pm 1.45 \mathrm{~b}$ & $28.6 \pm 1.71 \mathrm{~b}$ \\
& Low & $4.67 \pm 0.58 \mathrm{a}$ & $0.71 \pm 0.03 \mathrm{a}$ & $14.0 \pm 0.26 \mathrm{a}$ & $4.59 \pm 0.84 \mathrm{a}$ & $11.8 \pm 1.33 \mathrm{a}$ \\
\hline \multirow{2}{*}{ Red } & High & $13.5 \pm 1.87 \mathrm{~b}$ & $1.86 \pm 0.12 \mathrm{~b}$ & $38.5 \pm 0.92 \mathrm{~b}$ & $14.6 \pm 1.78 \mathrm{~b}$ & $33.4 \pm 0.17 \mathrm{~b}$ \\
Amaranth & Medium & $10.1 \pm 0.35 \mathrm{~b}$ & $1.84 \pm 0.09 \mathrm{~b}$ & $35.7 \pm 3.62 \mathrm{~b}$ & $11.3 \pm 1.22 \mathrm{~b}$ & $30.1 \pm 1.05 \mathrm{~b}$ \\
& Low & $4.95 \pm 0.17 \mathrm{a}$ & $0.70 \pm 0.03 \mathrm{a}$ & $13.3 \pm 0.62 \mathrm{a}$ & $4.17 \pm 1.50 \mathrm{a}$ & $12.0 \pm 1.46 \mathrm{a}$ \\
\hline \multirow{3}{*}{ Amaranth } & High & $18.7 \pm 1.20 \mathrm{c}$ & $2.01 \pm 0.19 \mathrm{~b}$ & $41.0 \pm 2.40 \mathrm{c}$ & $15.6 \pm 2.19 \mathrm{~b}$ & $31.9 \pm 1.91 \mathrm{~b}$ \\
& Medium & $10.8 \pm 0.59 \mathrm{~b}$ & $1.71 \pm 0.16 \mathrm{~b}$ & $30.7 \pm 1.79 \mathrm{~b}$ & $14.9 \pm 1.31 \mathrm{~b}$ & $31.3 \pm 1.06 \mathrm{~b}$ \\
& Low & $5.07 \pm 0.24 \mathrm{a}$ & $0.78 \pm 0.17 \mathrm{a}$ & $15.2 \pm 2.05 \mathrm{a}$ & $4.04 \pm 0.63 \mathrm{a}$ & $12.3 \pm 0.82 \mathrm{a}$ \\
\hline
\end{tabular}

\begin{tabular}{llllll}
\hline Safe Limit $\left(\mu \mathrm{g} \mathrm{g}^{-1}\right)^{\mathrm{b}}$ & 100 & 3 & 50 & 50 & 100 \\
\hline
\end{tabular}

Mean values in the same column followed by the same letters are not significantly different $(P<0.01)$.

${ }^{\mathrm{b}}[$ Ewers U (1991).

\section{Relationship between soil and plant metal concentrations}

The correlation between the heavy metal contents in soils and their corresponding contents in vegetables indicated positive correlation, the $r$ values ranged from 0.599 to 0.999 (Table 6). The higher correlation between soil and plant corresponded to $\mathrm{Cr}$ in amaranth. On the other hand, comparatively lower correlation between soil-plant corresponded to $\mathrm{Cr}$ in spinach. However, the degree of relationship between soil and plant in respect of three locations was irregular.

\section{Bioconcentration factor}

Bioconcentration factor (BCF) of different heavy metals from soil to vegetables are one of the key components of human exposure to metals through the food 
chain (Table 7). It is calculated as the ratio between the concentration of heavy metals in the vegetables and that in the corresponding soil (all based on dry weight) for each vegetable separately (Liu et al., 2006). The TF values were below 1, and more TF values were obtained for $\mathrm{Ni}$ whereas it was less for $\mathrm{Co}$ as compared to $\mathrm{Pb}, \mathrm{Cd}$ and $\mathrm{Cr}$. The trend of $\mathrm{TF}$ for heavy metals in different leafy vegetables studied were in the order of $\mathrm{Ni}>\mathrm{Cd}>\mathrm{Pb}>\mathrm{Cr}>\mathrm{Co}$. The TF values ranges were: $\mathrm{Pb} 0.153-0.500, \mathrm{Cd} 0.383-0.675$, Ni $0.340-0.878$, Co $0.110-0.309$, and $\mathrm{Cr} 0.181-0.215$. These values were higher than those observed (Ahmad and Goni, 2009). The degree of TF showed irregular pattern in high-level polluted, medium-level polluted and low-level polluted areas, however the trend of TF for location were polluted (either high-level or medium-level)>low-level polluted.

Table 6. Correlations between heavy metal content ${ }^{\S}$ in soils and in vegetables $(\S=\mu \mathrm{g}$ $\mathrm{g}^{-1}$ of dry wt., ${ }^{*}=p<0.05, * *=p<0.01$, ns=not significant)

\begin{tabular}{c|l|c|c|c|c|c}
\hline Vegetable & $\begin{array}{c}\text { Level of } \\
\text { pollution in } \\
\text { the growing } \\
\text { area }\end{array}$ & $\mathrm{Pb}$ & $\mathrm{Cd}$ & $\mathrm{Ni}$ & $\mathrm{Co}$ & $\mathrm{Cr}$ \\
\hline \multirow{2}{*}{ Spinach } & High & $0.8538 \mathrm{~ns}$ & $0.8350 \mathrm{~ns}$ & $0.9965^{* *}$ & $0.9934^{*}$ & $9690^{*}$ \\
& Medium & $0.9944^{* *}$ & $0.9087 \mathrm{~ns}$ & $0.9402 \mathrm{~ns}$ & $0.9794^{*}$ & $8039 \mathrm{~ns}$ \\
& Low & $0.6547 \mathrm{~ns}$ & $0.9920^{* *}$ & $0.8232 \mathrm{~ns}$ & $0.8846 \mathrm{~ns}$ & $8975 \mathrm{~ns}$ \\
\hline \multirow{2}{*}{ Red } & High & $0.9707^{*}$ & $0.9824^{*}$ & $0.9440 \mathrm{~ns}$ & $0.9665^{*}$ & $0.9381 \mathrm{~ns}$ \\
Amaranth & Medium & $0.8496 \mathrm{~ns}$ & $0.9839^{*}$ & $0.9902^{* *}$ & $0.8181 \mathrm{~ns}$ & $0.9709^{*}$ \\
& Low & $0.9041 \mathrm{~ns}$ & $0.6698 \mathrm{~ns}$ & $0.9868 *$ & $0.9687 *$ & $0.9992^{* *}$ \\
\hline \multirow{2}{*}{ Amaranth } & High & $0.9983 * *$ & $0.9278 \mathrm{~ns}$ & $0.9186 \mathrm{~ns}$ & $0.6833 \mathrm{~ns}$ & $0.9813^{*}$ \\
& Medium & $0.9498 \mathrm{~ns}$ & $0.9877 *$ & $0.9864 *$ & $0.9933^{* *}$ & $0.9931^{* *}$ \\
& Low & $0.8992 \mathrm{~ns}$ & $0.9317 \mathrm{~ns}$ & $0.5989 \mathrm{~ns}$ & $0.9331 \mathrm{~ns}$ & $0.9813^{*}$ \\
\hline
\end{tabular}

Table 7. Bioconcentration factor ( \pm , standard deviation) of $\mathrm{Pb}, \mathrm{Cd}, \mathrm{Ni}, \mathrm{Co}$ and $\mathrm{Cr}$ for the soils to vegetables species

\begin{tabular}{c|l|c|c|c|c|c}
\hline Vegetable & $\begin{array}{c}\text { Level of } \\
\text { pollution in } \\
\text { the growing } \\
\text { area }\end{array}$ & $\mathrm{Pb}$ & $\mathrm{Cd}$ & $\mathrm{Ni}$ & $\mathrm{Co}$ & $\mathrm{Cr}$ \\
\hline \multirow{5}{*}{ Spinach } & High & $0.290 \pm 0.014$ & $0.563 \pm 0.041$ & $0.833 \pm 0.002$ & $0.112 \pm 0.017$ & $0.189 \pm 0.014$ \\
& Medium & $0.337 \pm 0.046$ & $0.383 \pm 0.043$ & $0.878 \pm 0.072$ & $0.124 \pm 0.020$ & $0.190 \pm 0.013$ \\
& Low & $0.200 \pm 0.033$ & $0.675 \pm 0.033$ & $0.363 \pm 0.032$ & $0.110 \pm 0.032$ & $0.215 \pm 0.087$ \\
\hline \multirow{2}{*}{ Red } & High & $0.345 \pm 0.054$ & $0.466 \pm 0.005$ & $0.806 \pm 0.053$ & $0.156 \pm 0.007$ & $0.200 \pm 0.006$ \\
Amaranth & Medium & $0.441 \pm 0.044$ & $0.439 \pm 0.036$ & $0.788 \pm 0.083$ & $0.170 \pm 0.016$ & $0.214 \pm 0.016$ \\
& Low & $0.153 \pm 0.007$ & $0.415 \pm 0.025$ & $0.373 \pm 0.043$ & $0.227 \pm 0.124$ & $0.201 \pm 0.019$ \\
\hline \multirow{2}{*}{ Amaranth } & Hedium & $0.307 \pm 0.027$ & $0.500 \pm 0.087$ & $0.825 \pm 0.056$ & $0.156 \pm 0.017$ & $0.209 \pm 0.020$ \\
& Low & $0.500 \pm 0.049$ & $0.412 \pm 0.016$ & $0.742 \pm 0.032$ & $0.135 \pm 0.003$ & $0.203 \pm 0.007$ \\
\hline
\end{tabular}


The river Turag is highly polluted by industrial effluents, sewage sludge, municipal waste water and urban pollution. Vegetable lands irrigated with this water are contaminated, because more industrial effluents from various industrial sources enter into river. Additionally, little or no treatment is applied to the industrial discharges to detoxify the wastewater draining into rivers. However, the higher concentrations of $\mathrm{Pb}, \mathrm{Cd}, \mathrm{Ni} \mathrm{Co}$ and $\mathrm{Cr}$ in the polluted (either highlevel or medium-level) area indicates that industrial discharges add heavy metals into the soil.

\section{Conclusions}

Industrial effluents and urban pollution associated with sewage sludge, municipal waste water increased the levels of $\mathrm{Pb}, \mathrm{Cd}, \mathrm{Ni}, \mathrm{Co}$ and $\mathrm{Cr}$ intake of the vegetables and soils. To avoid entrance of metals into the food chain, industrial discharges should not be drained into rivers and farmlands without prior treatment. Considering human health hazard, it is recommended that these types of plants should not be cultivated in farms and fields irrigated by industrial waste water or water contaminated by heavy metals. These findings suggest further work by more controlled experiment, which should take into consideration of variations in uptake between different plant species, cropping history, fertilization and the levels of metals present in the soils and atmosphere.

\section{References}

Ahmad, J.A. and M.A. Goni. 2009. Heavy metal contamination in water, soil, and vegetables of the industrial areas in Dhaka, Bangladesh. Environ Monit Assess. DOI 10.1007/s10661-009-1006-6.

Alam, M.G.M., E.T. Snow and A. Tanaka. 2003. Arsenic and heavy metal contamination of vegetables grown in Samta village, Bangladesh. The Science of the Total Environment. 308: 83-96.

Alegria, A., R. Barberfi, R. Boluda, F. Errecalde, R. Farr and M. J. Lagarda. 1991. Environmental cadmium, lead and nickel contamination: possible relationship between soil and vegetable content. Fresenius Journal of Analytical Chemistry. 339: 654-657.

Al Jassir, M. S., A. Shaker and M. A. Khaliq. 2005. Deposition of heavy metals on green leafy vegetables sold on roadsides of Riyadh City, Saudi Arabea. B. Environ. Contam. Tox. 75: 1020-1027.

Arai, S. 2002. Global view on functional foods: Asian perspectives. Brit. J. Nutr. 88: S139-S143. Codex Alimentarius Commission, Contaminants. 1984. Joint FAO/WHO Food Standards Program, Codex Alimenturius, XVII.

Arora, M., B. Kiran, A. Rani, S. Rani, B. Kaur and M. Mittal. 2008. Heavy metal accumulation in vegetables irrigated with water from different sources. Food Chemistry. 111: 811-815.

Awashthi, S. K. 2000. Prevention of Food Adulteration Act No. 37 of 1954. Central and State rules as amended for 1999 (3rd ed.). New Delhi: Ashoka Law House. 
Bowen, H. J. M. 1966. Trace Elements in Biochemistry (p. 241). New York: Academic.

Ewers, U. 1991. Standards, guidelines and legislative regulations concerning metals and their compounds. In: Merian E, ed. Metals and Their Compounds in the Environment: Occurrence, Analysis and Biological Relevance. Weinheim: VCH, Pp: 458-468.

FAO/WHO - Codex Alimentarious Commission. 1984. Contaminants, Joint FAO/WHO Food standards Program (Vol. XVII, $1^{\text {st }}$ ed.). Geneva: Codex Alimentarious.

Farooq, M., A. Farooq and R. Umer. 2008. Appraisal of heavy metal contents in different vegetables grown in the vicinity of an industrial area. Pakistan Journal of Botany. 40(5): 2099-2106.

Farooq, M., R. K. Hans, P. N. Viswanathan and P. C. Joshi. 1999. Health hazard from dry river bed agriculture. Bull. Environ. Contam. Toxicol. 62:555-562.

Gupta, N., D. K. Khan and S. C. Santra. 2008. An assessment of heavy metal contamination in vegetables grown in wastewater-irrigated areas of Titagarh, West Bengal, India. Bulletin of Environmental Contamination and Toxicology. 80: 115-118.

Hanif, R., Z. Iqbal, M. Iqbal, S. Hanif and M. Rasheed. 2006. Use of vegetable as nutritional food role in human health. Journal of Agricultural and Biological Science. Pp: 18-20.

Islam, M. S., T. R. Tusher, M. Mustafa and S. Mahmud. 2012b. Effects of Solid Waste and Industrial Effluents on Water Quality of Turag River at Konabari Industrial Area, Gazipur, Bangladesh. Journal of Environtal Science and Natural Resources. 5(2): 213-218.

Islam, M. S., T. R. Tusher, M. Mustafa and S. L. Mamun. 2012a. Investigation of soil quality and heavy metal concentrations from a waste dumping site of Konabari industrial area at Gazipur in Bangladesh. IOSR Journal of Environmental Science, Toxicology and Food Technology. 2: 01-07

Jamali, M. K., T. G. Kazi, M. B. Arain, H. I. Afridi, N. Jalbani and A. R. Memon. 2007. Heavy metal contents of vegetables grown in soil, irrigated with mixtures of wastewater and sewage sludge in Pkistan, using ultrasonic-assisted pseudo-digestion. Journal of Agronomy \& Crop Science. 193: 218-228.

Kabata-Pendias, A. and H. Pendias. 1992. Trace elements in soil and plants (2nd ed., P. 365). Boca Raton: CRC.

Kashif, S. R, M. Akram, M. Yaseen and S. Ali. 2009. Studies on heavy metals status and their uptake by vegetables in adjoining areas of Hudiara drain in Lahore. Soil \& Environment. 28(1): 7-12.

Longman. 2005. Dictionary of contemporary English. Longman Nigeria Plc. McDonald, P., Edwards, R. A. and Greenhalgh, JFD (1995)

Liu, W., Li, X., Li, H.H.Sr. and Y. W. Wang. 2006. Heavy metal accumulation of edible vegetables cultivated in agricultural soil in the Suburb of Zhengzhou City, People's Republic of China. Bulletin of Environmental Contamination and Toxicology. 76: 163-170.

Li, N.Y., Li, Z.A., Zhuang, P., Zou, B., and M. Mcbride. 2009. Cadmium uptake from soil by maize with intercrops. Water, Air, Soil Pollution. 199:45-56. 
Lone, M. I., S. Saleem, T. Mahmood, K. Saifullah, and G. Hussain. 2003. Heavy metal contents of vegetables irrigated by Sewage/tubewell water. International journal of agriculture \& biology. 4:533-535.

Mingorance, M. D., B. Valdes, R. S. Oliva. 2007. Strategies of heavy metal uptake by plants growing under industrial emissions. Environment International. 33(4): 514-520.

Muchuweti, M., J. W. Birkett, E. Chinyanga, R. Zvauya, M. D. Scrimshaw and J. Lester. 2006. Heavy metal content of vegetables irrigated with mixture of wastewater and sewage sludge in Zimbabwe: Implications for human health. Agriculture Ecosystems \& Environment. 112:41-48.

Naser, H. M., N. C. Shil, N. U. Mahmud, M. H. Rashid and K. M. Hossain. 2009. Lead, cadmium and nickel contents of vegetables grown in industrially polluted and nonpolluted areas of Bangladesh. Bangladesh Journal of Agricultural Research. 34(4):545-554.

SEPA. 2005. The limits of pollutants in food. China: State Environmental Protection Administration GB2762-2005.

Sharma, R. K., M. Agrawal and F. Marshall. 2007. Heavy metal contamination of soil and vegetables in suburban areas of Varanasi, India. Ecotoxicology and Environmental Safety. 66:258-266.

Sharma, R. K., M. Agrawal and F. Marshall. 2006. Heavy metals contamination in vegetables grown in wastewater irrigated areas of Varanasi, India. Bulletin of Environmental Contamination and Toxicology. 77: 312-318.

Singh, K. P., D. Mohon, S. Sinha, R. Dalwani. 2004. Impact assessment of treated/untreated wastewater toxicants discharge by sewage treatment plants on health, agriculture and environmental quality in waste water disposal area. Chemosphere. 55: 227-255.

Somers, E. 1974. The toxic potential of trace metals in foods. A review. Journal of Food Science. 39: 215-217.

Tripathi, R. M., R. Raghunath and T. M. Krishnamoorthy. 1997. Dietary intake of heavy metals in Bombay city, India. The Science of the Total Environment. 208:149-159.

Misra, V. and P. K. Chaturvedi. 2007. Plant uptake/Bioavailability of heavy metals from the contaminated soil after treatment with humus soil and hydroxyapatite. Environmental Monitoring and Assessment. 133:169-176.

Wang, P. F., S. H. Zhang, C. Wang, J. Hou, P. C. Guo, and Z. L. Lin. 2008. Study of heavy metal in sewage sludge and in Chinese cabbage grown in soil amended with sewage sludge. African Journal of Biotechnology. 7(9):1329-1334.

Yong, S. O., E. L. Jung and H. M. Deok. 2011. Stabilization of Pb and Cd contaminated soils and soil quality improvements using waste oyster shells. Environmental Geochemistry and Health. 33:83-91.

Yusuf, A. A., T. A. Arowolo, O. Bamgbose. 2003. Cadmium, copper and nickel levels in vegetables from industrial and residential areas of Lagos City, Nigeria. Food and Chemical Toxicology. 41: 375-378. 
